www.nature.com/clinicalpractice/onc

\title{
Lenalidomide plus dexamethasone is efficacious in patients with relapsed or refractory multiple myeloma
}

Nikhil C Munshi, Constantine Mitsiades, Paul G Richardson and Kenneth C Anderson Nature Clinical Practice Oncology (2008) 5: 374-375 [doi:10.1038/ncponc1151]

\section{CORRIGENDUM}

In the Practice Point article by Munshi et al. published in the July 2008 issue of Nature Clinical Practice Oncology, it was not disclosed at the time of publication that one of the co-authors, Constantine Mitsiades, has competing interests. The correct competing interests information should read ' $\mathrm{C}$ Mitsiades receives Consultant honoraria from Millenium and Pharmion'. doi:10.1038/ncponc1212

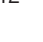

\section{Prognosis and outcomes of lymphocyte- predominant Hodgkin's lymphoma}

Grace Suh and Anas Younes

Nature Clinical Practice Oncology (2008) 5: 368-369 [doi:10.1038/ncponc1153]

\section{ERRATUM}

In the July 2008 issue of Nature Clinical Practice Oncology, the published online date for the Practice Point by Suh and Younes was incorrect. The article was published online on 10 June 2008. doi:10.1038/ncponc1213 